\title{
Distribution and Frequency of Occurrence of Endocrine Cells in the Proventriculus of Birds
}

\author{
Junzo Yamada, Toshihiko Iwanaga, \\ Tadayuki Yamashita and Mikio Misu \\ Department of Veterinary Anatomy, Obihiro University of \\ Agriculture and Veterinary Medicine, Obihiro-shi 080
}

(Received March 1, 1979)

\begin{abstract}
Argyrophil endocrine cells scattered in the proventriculus were identified under the light microscopy, but argentaffin cells appeared to be absent. All of the endocrine cells in the proventricular glands were closed type and they showed the ideal form as a mechanoreceptor cell. Topographic distribution and relative frequency of occurrence of the proventricular endocrine cells were clarified in the quail, chicken, pigeon, kite and gull. In the superficial epithelium, the endocrine cells were significantly numerous in the quail, few or rare in the chicken, pigeon and kite, and absent in the gull. In the proventricular glands, Grimelius-positive endocrine cells were characteristically distributed in the peripheral or outerhalf zone of glandular lobules. Hellerström-Hellmanpositive endocrine cells and lead-hematoxylin-positive endocrine cells were constantly found in middle zone of the glandular lobules in the chicken, quail and kite, whereas in the pigeon and gull they were randomly distributed. The endocrine cells in the proventricular glands were usually more numerous in the chicken than those in the other species examined.
\end{abstract}

Jap. J. Zootech. Sci., 50 (9): 653-659, 1979

In birds, the stomach is divided into two parts: proventriculus (glandular stomach) and gizzard (muscular stomach). Many round or polymorphic glandular lobules are present in the proventriculus. The exocrine cells of the proventricular glands are probably oxynticopeptic cells, that is, they secrete both hydrochloric acid and enzyme precursor pepsinogen ${ }^{1}$. The mucosal lining of the proventricular lumen is thrown into folds. The folds have been termed plicae and the intervening depressions called sulci ${ }^{2}$. From the bases of the sulci short, simple tubular glands frequently appear to extend into the lamina propria. However, these glands would appear to be an artifact of contraction $^{2}$. Therefore, the mucosal lining of the proventricular lumen is called superficial epithelium in this study. It is recognized that the proventriculus of birds and fundus of mammals are homologous organ. The proventriculus varies in size with species and foods of birds. It is relatively small in the grain-and seed-eating birds but is quite large and distensible in the carnivorous birds.

Although excellent reports have been made on the endocrine cells in the proventriculus $^{9-6)}$, there has never been any report concerning the relationship between the 
endocrine cells and foods and/or species of birds. This paper, therefore, is primarily concerned with the distribution and frequency of occurrence of the proventricular endocrine cells of the grain-eating and carnivorous birds.

\section{Materials and Methods}

Five adult birds from five avian species were used in this study. The first three groups, namely, chicken (Gallus gallus domesticus, 2 females and 3 males), quails (Coturnix coturnix japonica, 3 females and 2 males) and fantails (pigeon, Columba libia, 3 females and 2 males) are grain-eating birds. The second groups, black-eared kites (kite, Milvus migrans, 3 females and 2 males) and black-tailed gulls (gull, Larus crassirostris, 2 females and 3 males) are carnivorous birds. The proventriculi were dissected out and fixed in Bouin's fluid or buffered neutral formalin, dehydrated in ethanol, cleared in xylene and embedded in paraffin. To paraffin sections, the following methods were applied: Masson's argentaffin reaction"), Argyrophil methods of Grimelius $^{8)}$, Hellerström and Hellman ${ }^{*}$ and lead-hematoxylin ${ }^{10)}$.

Distribution and frequency of occurrence of the endocrine cells in the five species of birds were observed under light microscope.

\section{Results}

The argyrophil endocrine cells scattered in the superficial epithelium and proventricular glands were identified under light microscope by the selective reactivity of their cytoplasmic granules to Grimelius' silver, Hellerström-Hellman's silver and leadhematoxylin methods. An argentaffn endocrine cell appeared to be absent from the proventriculus of all the birds examined. The distributions and frequencies of occur-

Table 1. Distribution and frequency of occurrence of the endocrine cell in the proventriculus.

\begin{tabular}{|c|c|c|c|c|c|}
\hline & Quail & Chicken & Pigeon & Kite & Gull \\
\hline \multicolumn{6}{|l|}{ Superficial epithelium } \\
\hline Grimelius-positive cells & m & $H$ & + & + & - \\
\hline $\begin{array}{l}\text { Hellerström-Hellman } \\
\text { positive cells }\end{array}$ & Ht & + & + & + & - \\
\hline $\begin{array}{l}\text { Lead-hematoxylin- } \\
\text { positive cells }\end{array}$ & H & $H$ & - & + & - \\
\hline \multicolumn{6}{|l|}{ Proventricular glands } \\
\hline $\begin{array}{r}\text { Grimelius-positive cells } \\
\text { (distribution pattern) }\end{array}$ & $\begin{array}{c}\text { 冊 } \\
\text { (periphery) }\end{array}$ & $\begin{array}{c}\text { HIIt } \\
\text { (outer half) }\end{array}$ & $\begin{array}{c}\text { H } \\
\text { (outer half) }\end{array}$ & $\begin{array}{c}\text { \# } \\
\text { (periphery) }\end{array}$ & $\begin{array}{c}\text { H } \\
\text { (periphery) }\end{array}$ \\
\hline $\begin{array}{l}\text { Hellerström-Hellman- } \\
\text { positive cells } \\
\text { (distribution pattern) }\end{array}$ & $\begin{array}{c}\text { Ht } \\
\text { (middle) }\end{array}$ & $\begin{array}{c}\mathbb{H} \\
\text { (middle) }\end{array}$ & $\begin{array}{c}H \\
\text { (random) }\end{array}$ & $\begin{array}{c}+ \\
\text { (random) }\end{array}$ & $\begin{array}{c}H \\
\text { (periphery) }\end{array}$ \\
\hline $\begin{array}{l}\text { Lead-hematoxylin- } \\
\text { positive cells } \\
\text { (distribution pattern) }\end{array}$ & (middle) & $\begin{array}{c}\text { H } \\
\text { (middle) }\end{array}$ & $\begin{array}{c}+ \\
\text { (random) }\end{array}$ & $\begin{array}{c}\text { H } \\
\text { (middle) }\end{array}$ & $\begin{array}{c}+ \\
\text { (random) }\end{array}$ \\
\hline
\end{tabular}

$\mathbb{H}=$ highest; $\mathrm{H}$ =higher; $H=$ high; $+=$ low; $+=$ lower; $-=$ lowest (absent). 


\section{Endocrine Cells in Proventriculus}

rence of these endocrine cells varied with staining methods and species of birds, but did not show any variation to sex. The results were as follows.

\section{Grimelius-positive endocrine cells}

In basal part of the sulci of the superficial epithelium, the frequency of occurrence of the Grimelius-positive endocrine cells was high in the quail, low in the chicken, lower in the pigeon and kite, and the lowest (absent) in the gull (Table 1). Almost all these cells were oval in shape and were covered with the epithelial cells, but sometimes they had long cytoplasmic processes along the basal lamina (Figs. 1, 2).

In the proventricular glands, the endocrine cells were mainly found in the peripheral or outer half zone of the glandular lobules in all birds examined (Fig. 4). Their cytoplasmic processes were characteristically elongated along the long axis of tubular gland (Fig. 7). When sections were cut tangentially, they exhibited a stellate cell body with long two to four cytoplasmic processes containing argyrophil granules (Fig. 7). Even in transvererse sections of tubular glands, they also showed long cytoplasmic processes (Fig. 8). Thus, they might be multipolar cells. Their cytoplasmic processes were long and slender, sometimes, they displayed angular branching (Fig. 7). These endocrine cells were located between the exocrine cells and the basal lamina, and never extended their cytoplasm to glandular lumen. The frequency of occurrence of the endocrine cells was the highest in the chicken, higher in the quail, pigeon, kite and gull (Table 1).

\section{Hellerström-Hellman-positive endocrine cells}

In the basal part of the sulci of the superficial epithelium, the frequency of occurrence of the Hellerström-Hellman-positive endocrine cells were higher in the quail, lower in the chicken, pigeon and kite, and the lowest (absent) in the gull (Table 1). Almost all these endocrine cells were oval or triangular in shape. The endocrine cells rarely extended their apical processes to the glandular lumen (Fig. 3).

In the proventricular glands, the endocrine cells showed elongated form in the longitudinal sections of tubular glands (Fig. 9), but they were oval or round without cytoplasmic process in the transverse sections (Fig. 10). Therefore, these endocrine cells might be bipolar cells. Most of their cytoplasmic processes were shorter and thicker than those of the Grimelius-positive endocrine cells and did not show any angular branching (Fig. 9). These endocrine cells were almost located in middle zone of the glandular lobules in the chicken (Fig. 5), quail and kite, peripherally in the gull and randomly in the pigeon. The frequency of occurrence of the endocrine cells were higher in the chicken, high in the quail, and low in the pigeon, kite and gull (Table 1). Generally, the frequency of occurrence of the Hellerström-Hellman-positive endocrine cells was lower than that of the Grimelius-positive endocrine cells in all species examined.

\section{Lead-hematoxylin-positive endocrine cells}

In the basal parts of the sulci of the superficial epithelium, the frequency of occurrence of the lead-hematoxylin-positive endocrine cells was high in the quail, low in 


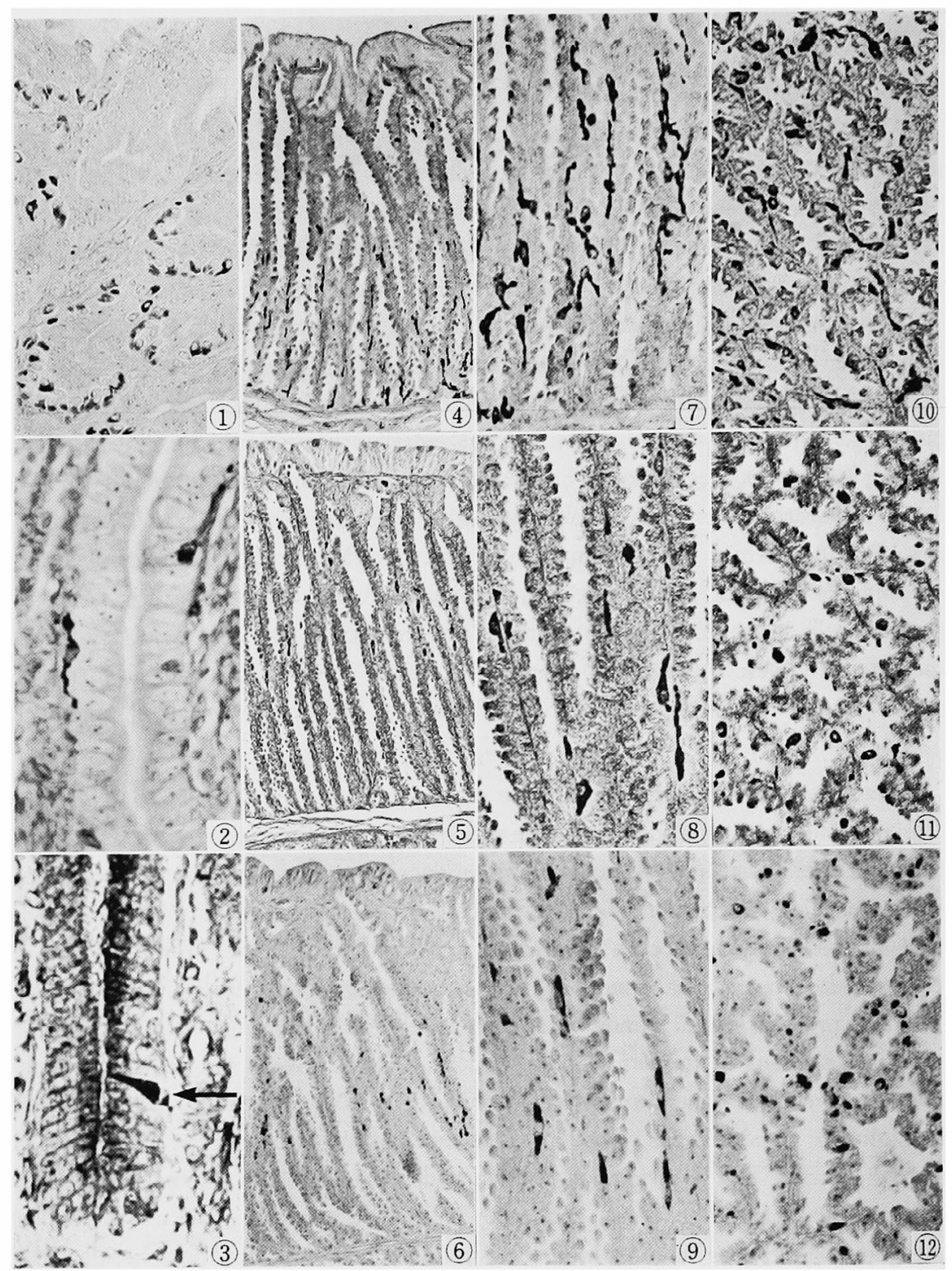

\section{Explanation of Figures}

Figs. 1-3. Argyrophil endocrine cells in the superficial epithelium.

Fig. 1. Numerous endocrine cells are found in the quail. Grimelius' silver, $\times 260$.

Fig. 2. Note the endocrine cell having long cytoplasmic processes. Chicken; Grimelius' silver, $\times 860$.

Fig. 3. Arrow shows open-type endocrine cell. Kite; Hellerström-Hellman's silver, $\times 520$.

Figs. 4-6. Photomicrographs showing the distribution patterns of the endocrine cells in the proventricular glands of the chicken. 
the chicken, lower in the kite, and the lowest (absent) in the pigeon and gull ( $\mathrm{Ta}$ ble 1). These cells were oval or triangular in shape.

In the proventricular glands, the shape, the topographical distribution and the frequency of occurrence of these endocrine cells were similar to those of the Hellerström-Hellman-positive endocrine cells (Table 1 and figs. 6, 11, 12), but in the gull, the lead-hematoxylin-positive endocrine cells were randomly distributed in the glandular labules (Table 1).

\section{Discussion}

DaWson and MoYer ${ }^{3)}$, AITKEN ${ }^{4}$, GABE ${ }^{5}$, and OKAmoto et al. ${ }^{6)}$ reported that there were many argyrophil endocrine cells in the proventriculus but no argentaffin cells. This finding was also confirmed by the present study. $\mathrm{GABE}^{\mathrm{b}}$ ) also described gastrin cells which were stained by lead-hematoxylin, HCl-toluidine blue, Grimelius' and Hellerström-Hellman's silver methods in the proventriculus in eight species of birds. However, he did not examine any carnivorous birds, and did not pay any attention to the relationship between the distribution and frequency of occurrence of the endocrine cells and the nature of feeds and/or species of birds. Furthermore, his "gastrin cells" might not be gastrin cells, because, the gastrin cells are never found in the proventriculus by immunohistochemistry ${ }^{11,12,13}$.

Almost all the endocrine cells of the proventricular glands characteristically displayed elongated cytoplasmic processes along the long axis of tubular gland. Especially, the Grimelius-positive endocrine cells had elongated processes like a multipolar nerve cell and a basket cell. These endocrine cells were classified into closed-type endocrine cells which were located between the exocrine cells and the basal lamina, and never extended their apical cytoplasm to the glandular lumen. КовауAsнi $e t$ al. ${ }^{14)}$ reported that all the endocrine cells in the human gastric fundus were classified into closed type. It is recognized that the proventriculus of birds and the fundus of mam-

Fig. 4. Very numerous Grimelius-positive endocrine cells are distributed in the outer half zone of the glandular lobule. $\times 220$.

Fig. 5. Numerous Hellerström-Hellman-positive endocrine cells are found in the middle zone. $\times 220$.

Fig. 6. Numerous lead-hematoxylin-positive endocrine cells situate in the middle zone. $\times 220$.

Figs. 7-12. Photomicrographs showing the shape of the endocrine cells in the proventricular glands of the chicken. All the endocrine cells are closed type.

Fig. 7. Longitudinal section of the glandular tubules. Multipolar endocrine cells are found. Note the angular branching of the cytoplasmic processes. Grimelius' silver. $\times 560$.

Fig. 8. Transverse section of the glandular tubules. Elongated endocrine cells are found. Grimelius' silver, $\times 560$.

Fig. 9. Longitudinal section. Compare with Fig. 7. Hellerström-Hellman's silver, $\times 560$.

Fig. 10. Transverse section. Compare with Fig. 8. Elongated cell is never found. HellerströmHellman's silver, $\times 560$.

Fig. 11. Longitudinal section. Angular branching of the cytoplasmic processes is never found. Lead-hematoxylin, $\times 560$.

Fig. 12. Transverse section. All the endocrine cells are oval or round in shape. Lead-hematoxylin, $\times 560$. 
mals are homologous organ. It is interesting to note that all the endocrine cells were closed type in the acid-secretory organs of birds and humans. Fujita and KoBayashi ${ }^{15}$ ) conceived the hypothesis that the closed-type endocrine cells might receive mechanical st.muli such as pressure and tension caused by foods. From this point of view, the endocrine cells of the proventricular glands showed the ideal form as a mechanoreceptor cell.

The topographic distribution and the frequency of occurrence of the proventricular endocrine cells were clarified in this study in the quail, chicken, pigeon, kite and gull. In the superficial epithelium, the endocrine cells were significantly numerous in the quail, but the significance of these numerous endocrine cells is not clear. In the proventricular glands, the Grimelius-positive endocrine cells were more numerous in the chicken than those in the other species examined, and these cells were characteristically distributed in the peripheral or outer half zone of the glandular lobules. The Hellerström-Hellman-positive endocrine cells and the lead-hematoxylin-positive endocrine cells were also more numerous in the chicken than those in the other species examined, and these cells were mainly found in the middle zone of the glandular lobules in the chicken, quail and kite, whereas in the pigeon and gull, they were random. ly distributed. From these findings, it is suggested that there are at least two types of endocrine cells in the proventriculus. Although these differential patterns of distribution of the endocrine cells were described in the mammalian pancreatic islets ${ }^{16,17,18}$, there is no report in the digestive tract. It is interesting to note that there are the differential patterns of distribution in the proventricular endocrine cells.

Although the chicken and quail are classified into the same family and take similar foods, their frequencies of occurrence of the endocrine cells were significantly different. The chicken, quail and pigeon are generally called the grain-eating birds, however, the distribution and frequency of occurrence of the endocrine cells in the pigeon resembled neither to those in the chicken nor quail. Instead, they resembled to those in the kite and gull. The kite and gull are carnivorous birds, but they are classified into the different order. Furthermore, there are some minor differences between their foods. It is likely that these differences have an influence on the distribution and frequency of occurrence of the proventricular endocrine cells. In this study, the differences on the distribution and frequency of occurrence of the proventricular endocrine cells were clarified in the species examined. However, these differences. could not be explained sololy by foods.

\section{References}

1) Menzies, G. and A. Fisk, Q. J. micros. Sci., 104: 207-215. 1963.

2) HoDges, R. D., The histology of the fowl. 48-49. Academic press. London. 1974.

3) Dawson, A. B. and S. L. Moyer, Anat. Rec., 100: 493-515. 1948.

4) Aitken, R. N.C., J. Anat., 92: 453-466. 1958.

5) GaBe, M., Arch. Anat. microsc., 61: 175-200. 1972.

6) Oкamoto, T., M. Sugrmura and N. Kudo, J. Fac. Fish. Anm. Husb. Hiroshima Univ., 127134. 1976. 
7) Singh, I., Anat. Anz., 115: 81-82. 1964.

8) Grimelius, L., Acta Soc. Med. Upsal,, 73: 243-270. 1968.

9) Hellerström, C. and B. HellmaN, Acta endoctinol. (Kbh), 35: 518-532. 1960.

10) Solcia, E., C. Capella and G. Vassallo, Histochemie, 20: 116-126. 1969.

11) Polak, J.M., A. G.E. Pearse, C. Adams and J. C. Caraud, Experientia (Basel), 30: 564-567. 1974.

12) Larsson, L.-I., F. Sundler, R. Håkanson, J. F. Rehfela and F. Stadil, Cell Tiss. Res., 154: 409-421. 1974.

13) Yamada, J., M. Yoshino, T. Yamashita, M. Misu and N. Yanaihara, Arch. histol. jpn., 42: 33-39. 1979.

14) Kobayashi, S., T. Fujita and T. Sasagawa, Arch. histol. jpn., 32: 429-444, 1971.

15) Fujita, T. and S. Kobayashi, Z. Zellforsch. microsk. Anat., 116: 52-60. 1971.

16) Orci, L., D. Daeteus, M. Ravazzola, F. Malaisse-Lagae, M. Amherdt and C. Rufener, in Endocrine Gut and Pancreas. (Fujita, T., ed.) 73-88. Elsevier. Amsterdam. 1976.

17) Erlandsen, S. L., O. D. Hegre, J. A. Parsons, R. C. McEvoy and R. P. Elde, J. Histochem. Cytochem., 24: 883-897. 1976.

18) Grube, D., V. Maier, S. Raptis and W. Schlegel, Histochemistry, 56: 13-35. 1978.

\title{
鳥の前胃における内分泌細胞の分布と出現頻度について
}

\author{
山田純三・岩永敏彦・山下忠幸・三須幹男 \\ 帯広畜産大学獣医学科, 帯広市 080
}

ウズラニワトリ，八ト，トビおよびウミネュの前胃 の内分泌細胞を，光学顥微鏡で観察し，次の所見它得 た.

1. 観察された鳥の前胃の内分泌細胞は，すべて好銀 性細胞であり，銀親和性細胞は認められなかった。

2. 前胃の表在上皮では，特にウズラで多数，ニワト リで少数，ハトとトピでまれに内分泌細胞は諗められた が,ウミネコでは認められなかった。

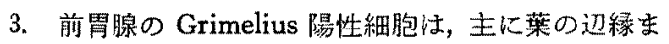
た注外側 $1 / 2$ 部分に分布していた. 本細胞は, ニワトリ で非常に多数，ウズラで多数，ハト，トビ，ウミネコで 中等度出現した。また本細胞は，多極性に細く, 長い突 起をのばしていた。
4. 同部位の Hellerström-Hellman 陽性細胞は, ニワ トリ，ウズラ,トビで葉の中間带に，ウミネュでは辺緑 に主に分布していたが，八トでは不規則な分布を示し た. 本細胞は、ニワトリで多数，ウズラで中等度，一 ト，トビ，ウミネコでは少数であったまた本細胞は， 管状腺の長軸に沿って突起をのばした双極性の細胞で 䟚。

5. 同部位の鉛へマトキシリン陽性細胞は, ニワト リ，ウズラ，トビで葉の中間带に主に分布していなが， トビとウミネコでは不規則な分布を示した. 本細胞の出 現頻度と形態は, Hellerström-Hellman 陽性細胞とほぼ 同様であった。

日畜会報； $50(9) ： 653-659,1979$ 